\title{
Discussion on the Cultivation of Innovation and Entrepreneurship of Tourism Management Tutor
}

\author{
Chen Qin \\ Fuzhou University of International Studies and Trade, Fuzhou, Fujian, China,350202
}

Keywords: tourism management tutor; innovation and entrepreneurship; ability training

\begin{abstract}
The transformation of China's local colleges and universities to applied technology colleges and universities requires professional teachers with the ability to guide students' innovation and entrepreneurship as mentors. The formation of the ability of tourism management professional teachers requires the school to provide corresponding innovation and entrepreneurship training contents according to the tourism industry post standards. It is necessary for the school to set up a management system that encourages innovation and entrepreneurship, and provides comprehensive support for the innovation and entrepreneurship of tourism management professional teachers. This paper analyzes the current situation and existing problems of innovation and entrepreneurship in domestic colleges and universities. The concept of education is introduced on the basis of the ability cultivation of current tourism management professional innovation and entrepreneurship.
\end{abstract}

\section{Introduction}

With the continuous growth of tourism demand around the world, there are a lot of entrepreneurial opportunities in the very broad tourism industry. Tourism provides a very rich soil for the development of entrepreneurial economy. However, the state of entrepreneurship and development of tourism industry at home and abroad shows that the development of education is far from the development level. Therefore, the development of education in university tourism management is the inevitable requirement of education development. Innovation and entrepreneurship education is inseparable from institutions of higher learning. The innovation and entrepreneurship education of application-oriented universities is an expression of social development needs. Innovation and entrepreneurship education is an important means to highlight the characteristics of application-oriented undergraduate institutions, and it is a breakthrough to promote the development of connotation. Therefore, how to seize the opportunity of innovation and entrepreneurship education to build a new education requirement for innovation and entrepreneurship, the teachers' team with the basic quality of "double energy" and the guidance ability of innovation and entrepreneurship is the main direction of the construction of innovation and entrepreneurship tutors in application-oriented universities. The characteristics of innovation and entrepreneurship instructors in application-oriented undergraduate colleges are that they have the basic quality of "double energy", and they also need to have the ability of innovation and entrepreneurship guidance. However, there are many problems to be solved in the construction of application-oriented innovation and entrepreneurship tutors.

The purpose of this study is to understand the development status of innovation and entrepreneurship tutors in application-oriented universities, and to find out the problems and analyze the main factors that influence the construction of this team. Under the premise of making clear the ability and quality requirements of innovative entrepreneurial instructors, this paper puts forward the practical Suggestions to help the development of the team of innovation and entrepreneurship, and makes the way for the cultivation of excellent application-oriented innovative talents. 


\section{The Importance of Ability Cultivation of Innovation and Entrepreneurship in Tourism Management Tutor}

\subsection{Conducive to the development of innovation and entrepreneurship education}

Chinese colleges and universities are increasingly relying on the resources provided by the society, and they need to continuously provide high-quality services to the society. In the cruel social competition, the development of Chinese universities is subject to their adaptability to environmental changes. Innovation and entrepreneurship education provides new ideas for China's higher education reform and economic society. It is in line with China's current situation that applied undergraduate colleges should strengthen the construction of the mentor team for innovation and entrepreneurship. It is the key to build an innovation-oriented country and improve national competitiveness.

\subsection{Conducive to the cultivation of innovative entrepreneurial talents}

Teachers' innovation quality is a sufficient and necessary condition for students to cultivate their innovative ability. At present, in the education of most application-oriented undergraduate institutions, the teaching team is generally lacking in entrepreneurial practice experience. A large number of teachers not only lack the experience of starting a business, but also have not participated in the special training related to entrepreneurship education. We hope that such a contingent of teachers will be in vain. It is an important guarantee for us to build a team of teachers with both theory and practice to promote innovation and entrepreneurship education in application-oriented universities.

\subsection{Conducive to the development of application-oriented undergraduate institutions}

Teachers are the main body of the construction of the school, and bear the specific organizational goals and mission of the university, which is the most important and the most valuable asset of a university. The history of the world's leading universities has proved that world-class universities can not be left without a world-class faculty. The appearance and quality of education of innovation and entrepreneurship in colleges and universities depend greatly on the level of innovation and entrepreneurship tutor. Application-oriented undergraduate colleges and universities will innovate and entrepreneurship education through the process of talent cultivation. The construction of innovation and entrepreneurship tutor team will help to strengthen the connotation construction of applied undergraduate colleges and improve their innovation ability.

\subsection{Helpful for education manager to improve the management level}

It is helpful to optimize the structure of the faculty, establish the training system, evaluation system and guarantee system of application-oriented university teachers, and promote the specialization, systematization and systematization of teacher training and training. We study the innovation and entrepreneurship tutor team of applied undergraduate colleges. It is helpful to optimize the structure of the faculty, establish the training system, evaluation system and guarantee system of application-oriented university teachers, and promote the specialization, systematization and systematization of teacher training and training. The exploration of the construction of application-oriented undergraduate innovation and entrepreneurship tutors is conducive to the implementation of "people-oriented" management concept of education managers in colleges and universities. We should make scientific and rational selection, appointment and motivation of teachers, correctly grasp the psychological trend of teachers, arouse the potential of teachers and improve the level of governance. 


\section{The Construction of Innovation and Entrepreneurship Tutors in Undergraduate Institutions}

\subsection{Innovation and entrepreneurship mentor management needs to be standardized}

Chinese colleges and universities have no systematic management system of innovation and entrepreneurship tutor team. The first, the scientification of the innovation and entrepreneurship instructors in the selection of employment should be further standardized. The second, the evaluation and evaluation of innovation and entrepreneurship tutors need to be explored. The third, the lack of guarantee system of the innovation and entrepreneurship mentor team is not in place for the promotion and incentive measures for the innovation and entrepreneurship mentors. The fourth, the lack of a scientific and smooth promotion path for the innovation and entrepreneurship mentor team has limited the enthusiasm of teachers. In general, the management mechanism of innovation and entrepreneurship tutor is not quite complete, and the perfect management system of innovation and entrepreneurship is not yet formed.

\subsection{The quality of innovation and entrepreneurship tutors needs to be improved}

One of the outstanding problems in the construction process of Chinese universities innovation and entrepreneurship tutors is that teachers' professional level is not high. At present, the number of teachers who are engaged in innovation and entrepreneurship education teaching and academic research in Chinese universities is small. Chinese universities have not yet formed excellent teaching and research teams. For innovation and entrepreneurship education, the actual work content is increasingly complex, and the work content and work area are constantly expanding. In this way, it is not only necessary for the innovation and entrepreneurship instructors to master the open and comprehensive knowledge structure and skills system, but also require them to carry out in-depth research and practice. However, the reality is that there is a large gap between the teachers' ability to engage in innovation and entrepreneurship education, and the professional level also needs to be improved.

\section{Improve the Construction of Innovation and Entrepreneurship Tutors in Chinese Colleges and Universities}

\subsection{Build the education teaching team platform in the innovation and entrepreneurship training}

Chinese colleges and universities should set up many kinds of innovation and entrepreneurship education teaching team, so that teachers can participate widely. We should give full play to the role of innovation and entrepreneurship education teaching team leader. Team leaders have different roles to play in different periods of team building. In the early stage of the team's establishment, it is necessary to carry out the basic problems of the development direction and construction goal of education teaching team. In the process of team building promotion, the team leader should give full play to the monitoring function and authorize the team members flexibly. Team building of the responsibility and obligation to the people, implementing play team members' enthusiasm and initiative, let more team members involved in the team building on the spirit of ownership, exercise their own innovation ability, achieve the aim of innovative entrepreneurial team. The responsibility and obligation of team building will be put into practice, and the enthusiasm and initiative of team members will be brought into full play, so as to train their innovation and entrepreneurial ability and realize the team's innovation and entrepreneurship goals. Innovation and entrepreneurship education teaching team's formation and construction can make tourism management professional teachers innovative and entrepreneurial ability to improve the multiplier. Innovation and entrepreneurship team cooperation should emphasize the communication between team members, and support each member's initiative to communicate with other members, so as to facilitate the communication of team members. By enhancing mutual trust and dependence, team members are willing to share resources and interpersonal support and strengthen team cohesion. In this way, we can improve the 
innovation and entrepreneurship performance of the teaching team, improve the ability of team members to innovate and entrepreneurship, and guide innovation and entrepreneurship.

\subsection{The system construction of innovation and entrepreneurship tourism management professional teachers}

We will establish a management system to promote teachers' ability to improve their innovation and entrepreneurship, and help them improve their ability to innovate and entrepreneurship. Some applied technology universities have made beneficial attempts to improve teachers' ability of innovation and entrepreneurship and have achieved good results. For example, the Chinese universities provide financial support to the teaching team of innovation and entrepreneurship tutors, provide subsidies to team members, and stimulate the enthusiasm of tourism management professional teachers for the role cultivation of innovative entrepreneurial mentors. To enhance the ability of innovation and entrepreneurship mentors to become the consensus of tourism management professional teachers, we create an atmosphere of cultivating the role culture of innovation and entrepreneurship in this way. Chinese universities should also grasp the admission system of young teachers. In this way, the teacher who has been engaged in tourism management of Chinese universities can quickly grow up to be the tutor of the innovation and entrepreneurship activities of tourism management students.

\subsection{Cultivate a new type of dual-teacher teacher with innovative entrepreneurial guidance ability}

The traditional identification of double teacher teachers in China is based on the professional education. It is generally believed that the double-teacher type teacher refers to the teacher who has both professional theoretical knowledge and professional operational skills, and can combine professional theory with professional practice. This kind of cognition reflects the essential connotation of the double teacher type teacher, but lacks the scientific definition in the extension. In the real sense, double master teachers should not only understand the theoretical system of the specialized courses taught, but also understand the industrial development law of the teaching profession and the current situation of enterprise operation. According to the requirements of the industry enterprises to train their professional operation skills, and make their practical operation ability keep up with the requirements of The Times, walk in front of the employees. The key to achieving this goal is to actively participate in various professional practice activities. In the practice activities of industry enterprises, we constantly enhance the ability of innovation and entrepreneurship, so as to become a new type of double division with innovative entrepreneurial guidance and tourism management.

\section{Conclusion}

The construction of innovation and entrepreneurship tutor team is a key link to construct the education system of innovation and entrepreneurship in application-oriented universities. Applied undergraduate colleges and universities in the process of innovative undertaking teacher team construction features or advantages, is that it can double type teachers' training can be combined with the construction of innovative entrepreneurial tutors, creating high quality teachers. Colleges and universities should pay more attention to the cultivation of the innovative undertaking teacher team and reserves, with high standard, strict teacher talent selection and cultivation system, gathered a group of professional, expert of innovative entrepreneurial talent. Through the generous salary package and effective target incentive, perfect and perfect the mechanism of teacher talent protection.

\section{References}

[1] Barbara J. Bird, David N. Allen. Faculty Entrepreneurship in Research University Environment. Journal of Higher Education (1989) pp 586-587 
[2] Murray B. Low Ian. C. Mae Millan. Entrepreneurship: Past Rese are hand Future Challenges Journal of Management. Journal of Higher Education (2012) pp 139-161

[3] Zaghloul Morsy \& Philip G. Altbach. Higher Education in an International Perspective: Critical Issues, Garrland Publishing. Inc New York \& London (2010) pp 153

[4] Ardichvili A Cardozo RN, Ray S. A Theory of Entrepreneurial Opportunity Identification and Development. Journal of Business Venturing (2003) pp 105-123

[5] Begley TM, Boyd DP. Psychological Characteristics Associated with Performance in Entrepreneurial Firms and Smaller Businesses. Journal of Business Venturing (2007) pp 79-93

[6] Markley D. Entrepreneurial Support Organizations. Center for Rural Entrepreneurship Monograph (2013) pp 1-4

[7] Low MB, MacMillanI C. Entrepreneurship: Past Research and Future Challenges. Journal of Management (2008) pp 139-161

[8] Shane B, Venkataraman S. The Promise of Entrepreneurship as a Field ofResearch. Academy of Management Review (2010) pp 217-226 